\title{
BUNGA ANGGREK HITAM SEBAGAI IDE PENCIPTAAN KARYA BATIK PADA KAIN TENUN ULAP DOYO
}

Irma Indah Sari ${ }^{1}$ (suratnyairma@gmail.com, Pacasarjana Institut Seni Indonesia Yogyakarta)

\begin{abstract}
Black orchid flower is a natural plant typical of Borneo. The admiration of the authors of black orchid flowers aroused the writer's request to preserve this natural Kalimantan plant, by making artworks with the concept of batik that raised the theme of black orchid flowers. By making this work the author hopes that the community has concern and awareness of the black orchid flower and its natural habitat. This batik work will be poured on the woven Ulap Doyo which comes from doyo leaf fibers typical of East Kalimantan. The method used is discussing aesthetics and asking for empirical, while the method used is the method that uses S.P. Gustami, namely exploration, design, embodiment. When starting exploration, it starts with data collection. At the time of design, two designs were made and the designs were made through an embodiment process. This written batik works using traditional batik techniques using the canting process, the dye dye synthesis technique, the colet and the lorodan process. This work also has a unique impression that uses the basic ingredients of doyo weaving derived from doyo leaf fiber which has been through a long process, making it a unique webbing. This work is a batik work combined with doyo weaving. The work produced by the panel made of interior decoration, is accepted to be very flexible because it can only be interior decoration, besides being easily appreciated and conveyed the message can also encourage creative economic inspiration of local wisdom of the local community. The panel work that was made still used the original shape and color of the black orchid flower did not want to eliminate the character of the black orchid flower, but there were some that the author made with the author's creations such as curves on the stem and leaves. The colors created have bright colors and black that have characteristics such as Borneo and black orchid flowers that are not far from the theme taken, while the fining uses filigree figures.
\end{abstract}

Keywords: Black Orchid Flowers, Written Batik, Doyo Ulap Weaving

\section{ABSTRAK}

Bunga anggrek hitam merupakan tumbuhan alam khas Kalimantan. Kekaguman penulis akan bunga anggrek hitam menggugah keinginan penulis untuk melestarikan tanaman alam Kalimantan ini, dengan cara membuat suatu karya seni dengan konsep batik yang mengangkat tema bunga anggrek hitam. Dengan pembuatan karya ini penulis berharap agar masyarakat memiliki keperdulian dan kesadaran terhadap bunga anggrek hitam dan alam habitatnya. Karya batik ini akan dituangkan di atas tenun Ulap Doyo yang berasal dari serat daun doyo khas Kalimantan Timur. Metode pendekatan yang digunakan adalah pendekatan estetika dan pendekatan empiris, sedangkan metode penciptaan yang digunakan ialah metode penciptaan S.P. Gustami, yakni eksplorasi, perancangan, perwujudan. Pada tahap eksplorasi, penciptaan diawali dengan melakukan pengumpulan data. Metode pengumpulan data yang digunakan adalah studi pustaka. Karya batik tulis ini menggunakan teknik batik tradisional dengan menggunakan proses canting, teknik pewarnaan sintesis celup tutup, colet dan proses lorodan. Karya ini juga memiliki kesan yang unik dikarenakan menggunakan bahan dasar tenun ulap doyo yang berasal dari serat tumbuhan daun doyo yang telah melalui proses panjang, sehingga menjadi sebuah tenun yang unik. Karya ini merupakan karya batik yang dipadukan dengan tenun ulap doyo. Karya yang dihasilkan berupa kaya panel yang berfungsi sebagai hiasan interior, dirasakan 
sangat fleksibel karena bisa untuk hiasan interior dimana saja, selain mudah diapresiasi dan menyampaikan pesan juga dapat mendorong inspirasi ekonomi kreatif kearifan lokal masyarakat setempat. Karya panel yang diciptakan masih menggunakan bentuk dan warna asli pada bunga anggrek hitam dikarenakan tidak ingin menghilangkan karakter pada bunga anggrek hitam namun ada beberapa yang penulis kreasikan dengan kreasi penulis seperti lekukan pada batang dan daunnya. Warna-warna yang diciptakan memiliki warna-warna cerah dan gelap yang memiliki karakteristik seperti alam Kalimantan dan bunga anggrek hitam yang tidak jauh dari tema yang diambil, sedangkan sebagai fininghing-nya menggunakan figura kerawang.

Kata kunci : Bunga Anggrek Hitam, Batik Tulis, Tenun Ulap Doyo

\section{PENDAHULUAN}

Anggrek hitam dalam bahasa latinnya Coelogyne Panduarta Lindl, merupakan spesies anggrek yang berada di Kalimantan sebagai tumbuhan langka. Kelangkaannya disebabkan oleh periode berbunganya yang relatif pendek (cepat layu), tanaman juga sulit untuk diperbanyak dengan teknik konvensional seperti stek batang dan penggunaan anakan yang berada di pembelahan rumpun. Habitat anggrek hitam di hutan-hutan juga terancam oleh seringnya terjadi kebakaran hutan, beralihnya fungsi hutan, dan eksploitasi yang terjadi setiap tahun. Anggrek hitam sering ditemukan di daerah pesisir, yang tumbuh kebanyakan pada pohon pelawan dan tanah berpasir putih di dataran rendah. Tumbuhan ini mempunyai batang yang menjalar ke atas seperti umbi semu yang berbentuk bulat, memanjang dan pipih (Darsono,2000:5).

Keunikan yang dimiliki tumbuhan ini yaitu selalu mengeluarkan aroma harum, memiliki bibir berbelah tiga, dua diantaranya berhelai pendek, sedangkan belahan tengah berbentuk biola yang ujungnya berkerut dan pinggirannya keriting berwarna hitam pekat. Setiap bunga memiliki garis tengah tidak lebih dari $10 \mathrm{~cm}$, dan daun kelopaknya berbentuk runcing dengan warna agak hijau muda. Perbedaan dengan tumbuhan sejenis lainya terletak pada masa ketahanan yang hanya mampu fresh dalam kurun waktu tiga hari saja.
Hal tersebut biasa ditandai dengan adanya perubahan warna pada daun yang menguning tetapi pada bagian tengah atau lidah bibir tetap berwarna hitam pekat.

Bagi sebagian masyarakat Kalimantan Timur, anggrek hitam digunakan sebagai salah satu kelengkapan dalam ritual adat suku tertentu dan dijadikan bahan pengobatan tradisional. Keberadaannya sekarang dijadikan maskot flora puspa pesona untuk Provinsi Kalimantan Timur. Hal itu dilakukan untuk menjaga potensi sumber daya alam dan nilai kearifan lokal yang banyak tumbuh di lingkungan setempat (Darsono,2000:53). Pemerintah juga sudah membuat lampiran PP No. 7 Tahun 1999, ada ketentuan dalam undang- undang No. 5 Tahun 1990 yang isinya sebagai berikut :

1. Mengambil, menebang, memiliki, merusak, memusnahkan, memelihara, mengangkut dan memperniagakan tumbuhan yang dilindungi atau bagian-bagiannya dalam keadaan hidup atau mati.

2. Mengeluarkan tumbuhan yang dilindungi atau bagian-bagiannya dalam keadaan hidup atau mati dari suatu tempat di Indonesia ke tempat lain didalam atau diluar Indonesia (Pasal 21 ayat 2).

Situasi dan kondisi anggrek hitam yang dipandang penting oleh masyarakat di Kalimantan Timur telah membuka pemikiran penulis. Melalui tema ini penulis akan 
mencoba menciptakan karya-karya yang dapat mengunggah kesadaran bahwa selain terjadi indikasi kepunahan dan keindahan tiadataranya anggrek hitam yang merupakan fakta penting bagi masyarakat yang harus tetap terjaga. Keindahan visual dari tumbuhan ini juga menarik dijadikan sumber inspirasi yang dapat mendukung terbentuknya perwujudan karya. Prakondisi penulis dengan objek penelitian yang mempunyai nilai kearifan lokal menjadi sebuah dorongan dan daya tarik untuk menciptakan sebuah karya seni kriya tekstil berupa intstalasi. Bagi penulis pemilihan jenis karya instalasi interior dirasakan sangat fleksibel karena bisa untuk hiasan interior dimana saja, selain mudah diapresiasi dan menyampaikan pesan juga dapat mendorong inspirasi ekonomi kreatif kearifan lokal masyarakat setempat.

Dalam penciptaan ini akan menggunakan material tenun ulap doyo yang terbuat dari serat daun doyo. Motifnya dibuat menggunakan teknik batik tulis. Anggrek hitam ditransformasikan menjadi sebuah motif. Keunikan dan keindahan visual serta potensi kontribusi dari anggrek hitam bagi kearifan lokal diharapkan mampu memberikan nilai baru dalam perkembangan kesenirupaan khususnya seni kriya tekstil.

\section{METODE PENCIPTAAN}

Anggrek hitam adalah salah satu spesies anggrek yang dilindungi di Indonesia karena terancam kepunahan dihabitat aslinya, yang menyebabkan banyak anggrek dipohonpohon hutan hilang dari kehidupan alami ketika terjadi kebakaran hutan, beralihnya fungsi hutan, dan eksploitasi yang terjadi setiap tahun (Phillip,2002:121). Keindahan anggrek hitam yang tidak seindah nasipnya kini perlu adanya upaya membangun kesadaran diri setiap orang terhadap lingkungan alam sekitar. Dalam penciptaan ini penulis menggunakan metode pendekatan estetika
Menurut Jhon Dewey dalam bukunya Art as Experience, membedakan dua kategori pengalaman dalam menikmati karya seni yaitu pengalaman artistik dan pengalaman estetik. Pengalaman artistik adalah pengalaman seni yang terjadi dalam proses penciptaan karya seni, sedangkan pengalaman ini dirasakan oleh seniman atau pencipta seni pada saat melakukan aktivitas artistik yang dinamakan proses kreatif, sehingga pengalaman estetik adalah pengalaman yang dirasakan oleh penikmat terhadap karya dalam arti keindahan secara utuh. Metode penciptaan yang digunakan dalam pembutan karya seni ini menggunakan teori dari Sp. Gustami, yang mana teori ini sering disebut dengan "Tiga Tahap-Enam Langkah Proses Penciptaan Seni Kriya"(Gustami,2007:30) tahap pertama, eksplorasi yang terdiri dari 2 langkah yaitu langkah melakukan penggambaran jiwa, pengamatan lapangan, penggalian sumber informasi dan penggalian landasan teori seta acuan. Tahap Kedua, perancangan yang terdiri dari 2 langkah yaitu penuangan ide kedalam sketsa, serta langkah penuangan ide ke dalam model. Tahap yang ke 3 merupakan tahap perwujudan yang terdiri 2 langkah, yaitu mewujudkan berdasarkan model dan mengevaluasi tentang kesesuaian ide dan wujud produk yang bernilai seni dan juga ketepatan fungsi

\section{PEMBAHASAN}

Berikut ini adalah perencanaan karya yang akan diawali dengan pembuatan sketsa terpilih : 


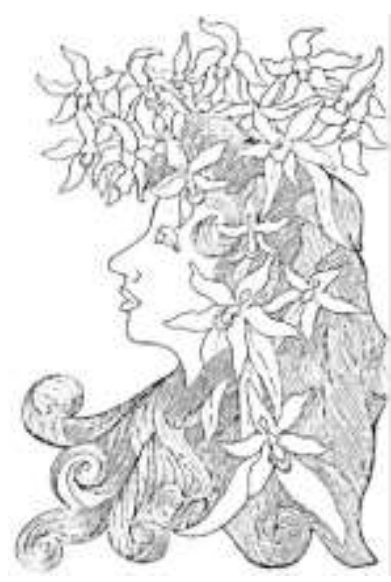

Gambar 1. Sketsa rancangan karya berjudul "Ratapan Hari Esok" (sketsa: Irma Indah Sari)

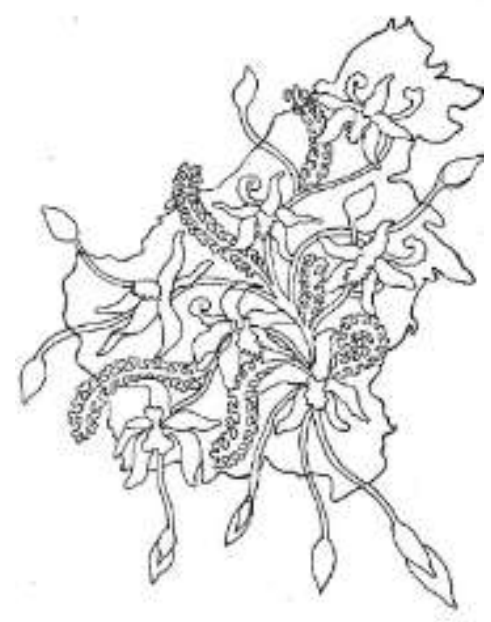

Gambar 2. Sketsa rancangan karya berjudul "Biarkan Aku Disini" (sketsa: Irma Indah Sari)

Bahan baku utama untuk mengerjakan karya ilmiah mengunakan bahan baku utama tenun ulap doyo. Tenun doyo merupakan tenun yang terbuat dari serat daun doyo, dengan melalui proses yang panjang sehingga terciptalah tenun doyo (Usman,1995:3) namun disini penulis menggunakan tenun doyo yang masih mentah atau masih murni tanpa campuran warna dan motif pada umumnya. Teknik yang digunakan dalam proses penciptaan karya adalah teknik batik tulis dan tutup celup dalam proses pewarnaanya. Alat yang mendukung dan sesuai dengan pengerjaan karya ilmiah ini yaitu canting, ember, kompor, wajan dan lainlain. Pewarnaannya mengunakan pewarna sintesis yaitu naptol dan idigusol.

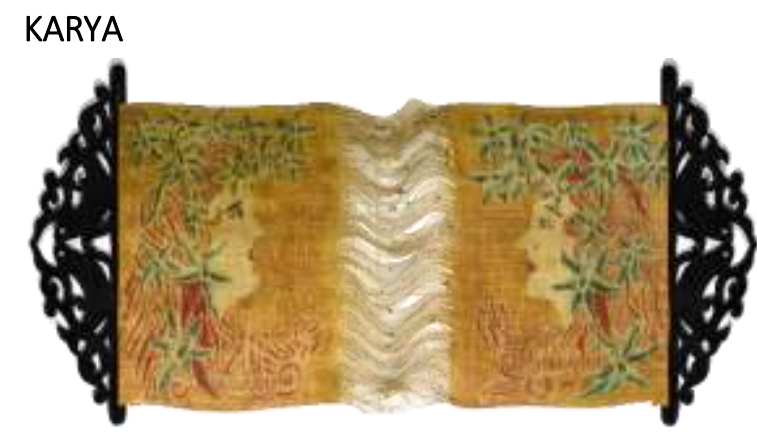

Gambar 3. Karya 1 berjudul "Ratapan Hari Esok", Teknik: Batik Tulis, Warna: Naptol dan Indigusol, Bahan: Tenun Ulap Doyo, Ukuran $48 \mathrm{~cm} \times 55 \mathrm{~cm}$, (Foto: Hidayat, 2017).

Karya ini penulis terinspirasi dari alam sekitar di Kalimantan yang kian hari kian memunah, banyaknya kebakaran hutan, eksploitasi secara berlabihan dan pengalihan fungsi hutan. Dari judul ratapan hari esok penulis mengangkat anggrek hitam selain memiliki unsur estetis juga sebagai ratapan hari esok karena kalau masyakarat sekililingnya tidak bentuk keperihatinan akan anggrek hitam dan mengajak masyarakat untuk lebih memperhatikan alam untuk bekal anak cucu dimasa depan, Warna hijau yang terkandung sebagai alam kalimantan yang dulunya hijau sedangkan warna merah dan orannye merupakan alam kalimantan sekarang telah gersang dan tidak sesejuk dahulu.

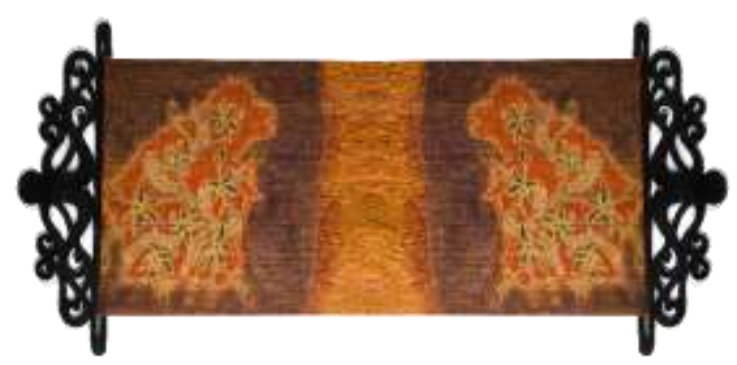

Gambar 4. Karya 2 berjudul "Dalam Kandungan Borneo”, Teknik: Batik Tulis, Warna: Naptol dan Indigusol, Bahan: Tenun Ulap Doyo, Ukuran: $48 \mathrm{~cm} \times 55 \mathrm{~cm}$, (Foto: Hidayat, 2017).

Karya ini merupakan karya yang terinspirasi dari kandungan seorang ibu, karena dialam azali kita hidup dan makan dari ibu kita. Karya ini membentuk pulau 
Kalimantan ditengahnya ada motif bunga anggrek hitam sebagai peran utama, karya ini masih menganut betapa pentingnya budidaya dan menjaga alam karena alam dan manusia hidup berdampingan, saling beradaptasi, saling menjaga demi bertahannya hidup hingga terdapat buah dari sebuah pengabdian seperti pengabdian seorang anak terhadap ibunya, dari segala pola pikir dan prilaku. Beground pada karya berwarna gelap yang memberi kesan magizt karena kedepannya kita tidak akan mengetahui apakah bumi dapat memberi kalau kita tidak menjaganya. Sedangkan alam borneo ibarat seorang ibu yang memberi makan pada anak nya.

\section{PENUTUP}

Alam merupakan ciptaan tuhan yang luar biasa, dengan alam lah manusia dapat beradaptasi dan mendapatkan penghasilan serta hidup. Dalam karya ini merupakan perwujudan dalam gabungan angrek hitam dan tenun ulap doyo dimana anggrek hitam sebagai sumber ide penciptaan sedangkan tenun ulap doyo sebagai bahan utamanya. Tenun ulap doyo merupakan tenun khas kalimantan timur yang terbuat dari serat daun doyo, yang merupakan kebanggan warga kalimantan timur namun disayangkan hanya beberapa orang saja yang masih menggeluti pembuatan kerjaninan tersebut. Adapun kendala dalam proses penciptaan ini yang pertama ialah tenun ulap doyo yang tidak dapat di blat (jiplak) dikarenakan memiliki tekstur yang kasar dan tebal, sedangkan pada saat proses pencantingan tidak berjalan semulus diatas kain katun dikarenakan bahan dasarnya yang kasar, bertesktur dan tebal. Hal ini membuat saat menorehkan malam agak sulit dan seringkali tersendat-sendat. Setelah melakukan proses pencantingan tahap selanjutnya melakukan pewarnaan. Pewarnaan mengunakan pewarna sintesis celup tutup, colet dan yang terakhir lorodan. Kendala yang kedua pada saat proses Iorodan dikarenakan warna tidak seterang pada saat menggunakan kain katun pada umumnya. Dikarenakan efek dari kain tenun yang terbuat dari serat daun. Namun kendala itulah yang membuat penulis semangat dan tetap optimis, dan tersadar bahwa karakteristik pada bahan dasar tersebut yang membuah kan hasil yang unik serta berbeda dari yang lain.

\section{DAFTAR PUSTAKA}

Darsono, KM.(2000), Anggrek Hitam Kalimantan Timur, Perhimpunan Anggrek Indonesia Cabang Samarinda, Samarinda.

Gustami, SP (2007), Butir-butir Mutiara Estetika Timur, Prasista, Yogyakarta.

Made Sukanadi, Studi dan Pencintaan Motif Nitik di Sentra Batik Kembangsongo Bantul.http://journal.isi.ac.id/index.php/c orak/article/view/2359

Phillip Cribb (2002), Indonesian Heritage, Tetumbuhan, Buku Antar Bangsa untuk Grolier International, Inc, Jakarta.

Usman Mulyati, Charlej. J. (1995), Tenun Ulap Doyo Daerah Kalimantan Timur, Mulawarman, Kalimantan Timur. 